with TAVI for intermediate-risk patients. It is not yet time for the sunset of SAVR!

\section{References}

1. Søndergaard L, Popma JJ, Reardon MJ, Van Mieghem NM, Deeb GM, Kodali S, et al. Comparison of a complete percutaneous versus surgical approach to aortic valve replacement and revascularization in patients at intermediate surgical risk: results from the randomized SURTAVI trial. Circulation. 2019;140:1296-305.

2. Leon MB, Smith CR, Mack MJ, Makkar RR, Svensson LG, Kodali SK, et al. Transcatheter or surgical aortic-valve replacement in intermediate-risk patients. N Engl J Med. 2016;374:1609-20.

3. Mack MJ, Leon MB, Thourani VH, Makkar R, Kodali SK, Russo M, et al. Transcatheter aortic-valve replacement with a balloon-expandable valve in low-risk patients. N Engl J Med. 2019;380:1695-705.

4. Harris RS, Yan TD, Black D, Bannon PG, Bayfield MS, Hendel PN, et al. Outcomes of surgical aortic valve replacement in octogenarians. Heart Lung Circ. 2013;22:618-26.

5. Langanay T, Flécher E, Fouquet O, Ruggieri VG, De La Tour B, Lelong B, et al. Aortic valve replacement in the elderly: the real life. Ann Thorac Surg. 2012;93:70-7.

6. Formica F, Mariani S, D'Alessandro S, Singh G, Di Mauro M, Cerrito MG, et al. Does additional coronary artery bypass grafting to aortic valve replacement in elderly patients affect the early and long-term outcome? Heart Vessels. 2020;35:487-501.

7. Zhou J, Liew D, Duffy SJ, Walton A, Htun N, Stub D. Cost-effectiveness of transcatheter aortic valve implantation compared to surgical aortic valve replacement in the intermediate surgical risk population. Int J Cardiol. 2019 294:17-22.

8. Muneretto C, Solinas M, Folliguet T, Di Bartolomeo R, Repossini A, Laborde F, et al. Sutureless versus transcatheter aortic valves in elderly patients with aortic stenosis at intermediate risk: a multi-institutional study. J Thorac Cardiovasc Surg. 2022;163:925-35.e5.

9. Barili F, Freemantle N, Pilozzi Casado A, Rinaldi M, Folliguet T, Musumeci F, et al. Mortality in trials on transcatheter aortic valve implantation versus surgical aortic valve replacement: a pooled meta-analysis of Kaplan-Meier-derived individual patient data. Eur J Cardiothorac Surg. 2020;58:221-9.

10. Goel S, Pasam RT, Wats K, Patel J, Chava S, Gotesman J, et al. Transcatheter aortic valve replacement versus surgical aortic valve replacement in low-surgical-risk patients: an updated meta-analysis. Catheter Cardiovasc Interv. 2019;1-10.

11. Hofer F, Hengstenberg C, Goliasch G, Grygier M, Mascherbauer J, Siller-Matula JM Transcatheter versus surgical aortic valve replacement in low-risk patients: a metaanalysis of randomized trials. Clin Res Cardiol. 2020;109:761-75.

12. Saleem S, Younas S, Syed MA. Meta-analysis comparing transcatheter aortic valve implantation to surgical aortic valve replacement in low surgical risk patients. Am J Cardiol. 2019;124:1257-64.

13. Makkar RR, Thourani VH, Mack MJ, Kodali SK, Kapadia S, Webb JG, et al Five-year outcomes of transcatheter or surgical aortic valve replacement. $N$ Engl J Med. 2020;382:799-809.

14. Reardon MJ, Van Mieghem NM, Popma JJ, Kleiman NS, Søndergaard L, Mumtaz M, et al. Surgical or transcatheter aortic-valve replacement in intermediate-risk patients. N Engl J Med. 2017;376:1321-31.

\title{
Commentary: The role of sutureless aortic valves in the transcatheter aortic valve replacement era
}

\author{
J. James Edelman, MBBS(Hons), PhD, \\ Christopher U. Meduri, MD, ${ }^{\mathrm{b}}$ and \\ Vinod H. Thourani, MD
}

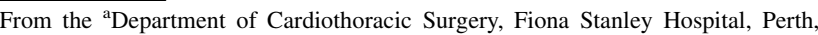
Australia; and ${ }^{\mathrm{b}}$ Division of Cardiology and ${ }^{\mathrm{c}}$ Department of Cardiovascular Surgery, Marcus Valve Center, Piedmont Heart Institute, Atlanta, Ga.

Disclosures: Dr Meduri reported advisor/research for Abbott Vascular, Edwards Lifesciences, Boston Scientific, and Medtronic. Dr Thourani reported advisor/research for Abbott Vascular, Edwards Lifesciences, Boston Scientific, Medtronic, and Gore Vascular. Dr Edelman reported no conflicts of interest.

The Journal policy requires editors and reviewers to disclose conflicts of interest and to decline handling or reviewing manuscripts for which they may have a conflict of interest. The editors and reviewers of this article have no conflicts of interest.

Received for publication May 11, 2020; accepted for publication May 12, 2020; available ahead of print May 25, 2020.

Address for reprints: Vinod H. Thourani, MD, Department of Cardiovascular Surgery, Piedmont Heart Institute, 95 Collier Rd, Suite 5015, Atlanta, GA 30308 (E-mail: vinod.thourani@piedmont.org).

J Thorac Cardiovasc Surg 2022;163:937-8

$0022-5223 / \$ 36.00$

Copyright (C) 2020 by The American Association for Thoracic Surgery

https://doi.org/10.1016/j.jtcvs.2020.05.043
}

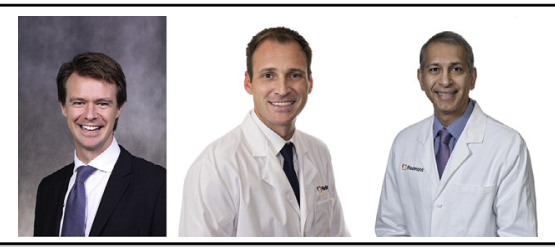

J. James Edelman, MBBS(Hons), PhD, Christopher U. Meduri, MD, MPH, and Vinod H. Thourani, MD

CENTRAL MESSAGE

Sutureless valves are an attrac-

tive alternative to surgical aortic

valve replacement (SAVR) in the

transcatheter era. However, little

clinical benefit has been demon-

strated compared to SAVR.

In this issue of the Journal, Muneretto and colleagues ${ }^{1}$ present a multi-institutional, retrospective study of intermediate-risk patients undergoing surgical aortic valve replacement (SAVR) with sutureless valves (SVs) or transcatheter aortic valve replacement (TAVR) for aortic stenosis. Patients were intermediate-risk based on a Society of 
Thoracic Surgeons Predicted Risk of Mortality score between $4 \%$ and $8 \%$. Patients were referred to SV or TAVR based on the decision of a multidisciplinary heart team; however, those undergoing TAVR were essentially not candidates for surgery. Just more than one half of patients in the SV group had full sternotomy and $28.4 \%$ of patients undergoing TAVR required transapical access. Before the propensity score matching, it remains quite clear that the patients undergoing TAVR are with greater comorbidities. After matching, the authors have minimized, yet not eliminated, these differences. They noted that 30-day mortality was lower in the SV group (1.4\% vs 5.5\%), as were lower levels of peripheral vascular complications and need for a permanent pacemaker. Hemodynamic results favored SVs, with lower rate of paravalvular regurgitation (PVR) and lower transvalvular gradient. At 5 years, the authors showed that patients with an SV had a significantly lower rate of mortality compared with TAVR $(16.1 \%$ vs $28.9 \%)$. The authors should be congratulated for their excellent results.

Retrospective analysis comparing TAVR and SAVR has some inherent confounding elements that cannot be adjusted with propensity matching. The most notable is that the patients who underwent TAVR (despite their similar Society of Thoracic Surgeons scores) were turned down for surgical intervention; therefore, they are inherently a greater-risk patient population. The authors are correct that large randomized trials have not compared SV with TAVR. It is possible that $\mathrm{SV}$ is superior to conventional SAVR, where previously no mortality difference with TAVR has been demonstrated in 2 large randomized series of intermediate-risk patients. ${ }^{2,3}$ Correspondingly, no study has yet been able to demonstrate a significant mortality benefit of a minimally invasive approach or SV compared with stented SAVR. ${ }^{4}$

An alternative explanation for the differences is the iteration of devices used for this study and the lack of adjudication by core laboratories on key variables. While there have been trivial modifications of the SV over the study period, there has been significant modifications to the TAVR prostheses. Specifically, this study notes a very high use of the transapical access $(\sim 28 \%)$, which has repeatedly been shown to have a greater mortality than surgery ${ }^{3}$ and is currently rarely used. Next, the TAVR valves used in this study are no longer commercially available and have been replaced with third-generation balloon- and selfexpanding technology that minimizes PVR. The authors have shown a $5.5 \%$ early mortality with TAVR, far greater than the contemporary randomized TAVR trials $(1.1 \%$ for SAPIEN 3). ${ }^{2,3,5}$

Although we applaud the authors for an excellent contribution and outcomes in the SV patients, we must be careful in that we cannot adjust for the biases of preoperative clinician assessment of risk without proper committee adjudication of each patient into the trial. This explanation is perhaps most likely, given the significant early and late mortality advantage of SV compared with TAVR, in the absence of large differences in factors known to decrease survival, such as PVR.

Proponents of sutureless prosthesis have argued that they include the best aspects of SAVR (removal of calcified leaflets and precise placement of the valve under vision in the arrested heart) and TAVR (minimally invasive and excellent hemodynamics). Critics argue that SVs suffer the same disadvantages as TAVR, namely high rates of pacemaker placement and PVR, albeit to a lesser extent. Also, they have noted that decreases of 10 to 15 minutes in aortic crossclamp times have not justified the cost associated with these devices. Surgery for aortic stenosis is not dead, and there are several clinical situations (high-risk anatomy, bicuspid aortic valves, young patients, dilated aorta) in which SAVR will remain the most appropriate therapywe agree that efforts should continue to improve this treatment. However, TAVR is attractive to patients due to the less morbid recovery. Data comparing these techniques with clinical events committee for 5 to 10 years are required for the appropriate management of these patients. We eagerly await a randomized trial comparing SV and TAVR in patients with severe, symptomatic aortic stenosis!

\section{References}

1. Muneretto C, Solinas M, Folliguet T, Di Bartolomeo R, Repossini A, Laborde F, et al. Sutureless versus transcatheter aortic valves in elderly patients with aortic stenosis at intermediate risk: a multi-institutional study. J Thorac Cardiovasc Surg. 2022;163:925-35.e5.

2. Reardon MJ, Van Mieghem NM, Popma JJ, Kleiman NS, Søndergaard L, Mumtaz M, et al. Surgical or transcatheter aortic-valve replacement in intermediate-risk patients. N Engl J Med. 2017;376:1321-31.

3. Makkar RR, Thourani VH, Mack MJ, Kodali SK, Kapadia S, Webb JG, et al. Fiveyear outcomes of transcatheter or surgical aortic-valve replacement. N Engl J Med. 2020;382:799-809.

4. Bilkhu R, Borger MA, Briffa NP, Jahangiri M. Sutureless aortic valve prostheses. Heart. 2019;105(suppl 2):s16-20.

5. Thourani VH, Kodali S, Makkar RR, Herrmann HC, Williams M, Babaliaros V, et al. Transcatheter aortic valve replacement versus surgical valve replacement in intermediate-risk patients: a propensity score analysis. Lancet. 2016;387: 2218-25. 